\title{
EFEKTIVITAS PELAKSANAAN PROGRAM GENERASI BERENCANA DALAM MENINGKATKAN KESEHATAN REPRODUKSI REMAJA DI KOTA YOGYAKARTA
}

\author{
Dwi Wiliantining Pyas ${ }^{1}$ dan Lena Satlita ${ }^{2}$
}

\begin{abstract}
This research aims to find out the effectiveness of the implementation of the Generasi Berencana program in Yogyakarta City along with the supporting and inhibiting factors. This research used qualitative approach with descriptive method. The results showed that the implementation of Generasi Berencana program in Yogyakarta City had not been effective, as seen from five indicators: (1) The policy had not been effective in overcoming teenagers problem, (2) Implementers had quite effective seen from the division of duties and authority, (3) The target had not been effective yet because the intervention target had not ready to support the Genre Program, (4) The policy environment had effective but the external environment had not been effective, and (5) The process had not been effective because teenagers and families with teenagers had not understood the substance of the GenRe Program. The supporting factors were the easiness of communication and counseling training. While the inhibiting factors were low public participation, moral deviation, and time limitations of each individual.
\end{abstract}

Keywords: Effectiveness, GenRe Program, dan Teenagers

\begin{abstract}
ABSTRAK
Penelitian ini bertujuan untuk mengetahui efektivitas pelaksanaan Program Generasi Berencana (GenRe) di Kota Yogyakarta beserta faktor pendukung dan faktor penghambatnya. Penelitian ini menggunakan pendekatan kualitatif dengan metode deskriptif. Hasil penelitian menunjukkan bahwa pelaksanaan Program Generasi Berencana (GenRe) di Kota Yogyakarta belum efektif dilihat dari lima indikator: (1) Kebijakan belum efektif dalam mengatasi permasalahan remaja. (2) Pelaksana cukup efektif dilihat dari pembagian tugas dan kewenangan meskipun memiliki keterbatasan sumberdaya manusia, (3) Target belum efektif karena target yang diintervensi belum siap mendukung Program GenRe, (4) Lingkungan kebijakan sudah efektif namun lingkungan ekternal belum efektif, dan (5) Proses belum efektif karena remaja dan keluarga yang mempunyai remaja belum memahami substansi Program GenRe. Faktor pendukungnya yaitu kemudahan dari komunikasi dan adanya pelatihan konseling. Beberapa penghambat antara lain rendahnya partisipasi masyarakat, adanya penyimpangan moral, dan keterbatasan waktu.
\end{abstract}

Kata Kunci: Efektivitas, Program GenRe, dan Remaja.

1,2 Jurusan Ilmu Administrasi Negara, Fakultas Ilmu Sosial, Universitas Negeri Yogyakarta 


\section{PENDAHULUAN}

Masa remaja adalah masa transisi dari masa kanak-kanak ke masa dewasa. Masa remaja ditandai dengan perubahan-perubahan fisik pubertas dan emosional yang kompleks, dramatis serta penyesuaian sosial yang penting untuk menjadi dewasa. Kondisi demikian membuat remaja belum memiliki kematangan mental oleh karena masih mencari identitas atau jati dirinya sehingga sangat rentan terhadap berbagai pengaruh dalam lingkungan pergaulan.

Masalah yang menonjol dikalangan remaja yaitu permasalahan seputar Tiga Resiko Dalam Kesehatan Reproduksi Remaja (TRIAD KRR) yang meliputi Seksualitas, NAPZA dan HIV/AIDS, rendahnya pengetahuan remaja tentang Kesehatan Reproduksi Remaja dan median usia kawin pertama perempuan relatif masih rendah yaitu 19,8 tahun.

Sehubungan dengan remaja dan permasalahannya, pemerintah memiliki Undang Undang yang membahas tentang hal tersebut, yaitu Undang Undang No. 52 Tahun 2009 tentang Perkembangan Kependudukan dan Pembangunan Keluarga pasal 48 ayat 1 (b) yang mengatakan bahwa "Peningkatan kualitas remaja dengan pemberian akses informasi, pendidikan, konseling dan pelayanan tentang kehidupan berkeluarga".

Dalam rangka mengemban amanat undang-undang dan merespon permasalahan remaja, BKKBN mengembangkan Program Generasi Berencana (GenRe) bagi remaja dan keluarga yang memiliki remaja yang sesuai dengan Tugas Pokok dan Fungsinya dilaksanakan oleh Direktorat Bina Ketahanan Remaja (Dithanrem). Program ini didasarkan pada Peraturan Kepala Badan Koordinasi Keluarga Berencana Nasional Nomor 47/HK.010/B5/2010 tentang Rencana Strategis Badan Koordinasi Keluarga Berencana Nasional 2010 - 2014 dan Addendum Peraturan Kepala Badan Kependudukan dan Keluarga Berencana Nomor 133/PER/B1/2011 tentang Rencana Strategis Badan Kependudukan dan Keluarga Berencana Tahun 20102014 untuk Pembangunan Kependudukan dan Keluarga Berencana.

Berdasarkan pertimbangan Rencana Strategis Badan Koordinasi Keluarga Berencana Nasional 2010-2014 maka diterbitkannya Grand Desain Program Pembinaan Ketahanan Remaja. Grand Desain Program Pembinaan 
Ketahanan Remaja ini merupakan acuan dan pedoman bagi Provinsi dan atau di Kabupaten dan Kota dalam rangka mengembangkan Program GenRe di berbagai tingkatan para khalayak pengguna.

Berdasarkan data jumlah penduduk di Kota Yogyakarta, penduduk dengan kelompok usia 10-14 tahun dan 15-19 tahun mempunyai jumlah yang paling tinggi di Kota Yogyakarta. Jumlah menurut kelompok usia 10-14 tahun mencapai 34.559 jiwa dan usia 15-19 tahun mencapai 34.200 jiwa. Sedangkan penduduk remaja usia 20-24 tahun berjumlah 29.561 jiwa. Namun, hingga saat ini masih banyak masyarakat khususnya remaja dan keluarga yang memiliki remaja yang tidak mengetahui apa itu Program Generasi Berencana (GenRe) dan tidak mengetahui atau bergabung di wadah Program Generasi Berencana (GenRe) yaitu Pusat Informasi Konseling Remaja/Mahasiswa (PIK R/M) dan Bina Keluarga Remaja (BKR). Meski BKKBN sudah sejak tahun 2010 meluncurkan program GenRe, sosialisasi kepada sasaran program belum optimal.

Berdasarkan data yang dihimpun dari Dinas Pengendalian Penduduk dan Keluarga Berencana (DPPKB) Kota
Yogyakarta pada tahun 2016 jumlah Pusat Informasi dan Konseling (PIK) remaja/mahasiswa di Kota Yogyakarta baru terdapat 54 PIK R/M dan belum memadai. Dari 54 PIK R/M di Kota Yogyakarta terdiri dari PIK $\mathrm{R}$ berbasis wilayah dan PIK $\mathrm{R}$ berbasis sekolah serta PIK $M$ berbasis kampus. Sedangkan untuk jumlah BKR di Kota Yogyakarta pada tahun 2016 yaitu 88 BKR. Adanya PIK R/M dan BKR merupakan ujung tombak dari Program Generasi Berencana (GenRe). Namun, tidak semua PIK R/M dan BKR tersebut yang berjalan dan aktif. Hal ini dikarenakan kegiatan dari Pusat Informasi dan Konseling R/M dan Bina Keluarga Remaja (BKR) ada yang masih belum berjalan atau tidak aktif.

Pelaksanaan Program GenRe masih mengalami kendala pada sasaran program yaitu remaja. Salah satu penyebab terjadinya kendala yaitu kurangnya sosialisasi kepada remaja dan rendahnya partisipasi remaja. Rendahnya partisipasi remaja karena remaja yang diundang dalam sosialisasi tidak datang. Kurangnya sosialisasi kepada remaja menunjukkan bahwa kampanye Program GenRe belum optimal sehingga masih ditemukan permasalahan remaja. Adapun permasalahan remaja di Kota Yogyakarta 
antara lain: persalinan pada remaja, kehamilan yang tidak diinginkan atau sering disebut dengan KTD, pernikahan dini, penyalahgunaan narkotika dan obat-obatan terlarang di kalangan generasi muda yang kian meningkat, dan aksi kenakalan remaja. Berdasarkan data tersebut terlihat bahwa pelaksanaan program Generasi Berencana di Kota Yogyakarta belum terlaksana dengan baik, masih terjadi permasalahan yaitu masih tingginya kasus permasalahan remaja. Oleh karena itu peneliti tertarik untuk meneliti lebih lanjut mengenai efektivitas pelaksanaan program Generasi Berencana di Kota Yogyakarta serta mengetahui faktor pendukung dan penghambatnya.

Anderson (1979:3) mendefinisikan kebijakan publik sebagai kebijakan yang ditetapkan oleh badan-badan dan aparat pemerintah. Harrold Laswell dan Abraham Kaplan berpendapat bahwa kebijakan publik hendaknya berisi tujuan, nilai-nilai, dan praktika-praktika sosial yang ada dalam masyarakat (Subarsono, 2013:2). Efektivitas merupakan unsur pokok untuk mencapai tujuan atau sasaran yang telah ditentukan di dalam setiap organisasi, kegiatan ataupun program. Disebut efektif apabila tercapai tujuan ataupun sasaran seperti yang telah ditentukan. Hal ini sesuai dengan pendapat H. Emerson yang dikutip Soewarno Handayaningrat $S$. (1994:16) yang menyatakan bahwa efektivitas adalah pengukuran dalam arti tercapainya tujuan yang telah ditentukan sebelumnya. Dalam penelitian ini untuk mengukur efektivitas pelaksanaan program Generasi Berencana di Kota Yogyakarta menggunakan indikator lima tepat yang dikemukakan oleh Riant Nugroho (2011:650). Pada indikator ini terdapat lima tepat yang dapat digunakan untuk mengukur efektivitas yaitu :(1) Tepat Kebijakan, (2) Tepat Pelaksana, (3) Tepat Target, (4) Tepat Lingkungan, (5) Tepat Proses.

\section{METODE}

Penelitian ini menggunakan pendekatan kualitatif dengan metode deskriptif. Data Primer diperoleh dari hasil observasi dan wawancara dengan informan penelitian terkait dengan efektivitas pelaksanaan program Generasi Berencana di Kota Yogyakarta sedangkan data sekunder diperoleh dari dokumentasi yang didapat di lokasi penelitian. Teknik analisis data dalam penelitian ini menggunakan teknik analisis interaktif yang dikemukakan oleh Milles dan Huberman (Sugiyono, 2011:246). 


\section{HASIL DAN PEMBAHASAN}

Program GenRe ini telah digalakkan ke seluruh penjuru Indonesia dengan BKKBN bekerjasama dengan SKPD-KB di masing- masing daerah sebagai motor utama pelaksana program. Melalui Bidang Keluarga Berencana dan Pembangunan Keluarga, Dinas Pengendalian Penduduk dan Keluarga Berencana Kota Yogyakarta berupaya memberikan pemahaman dan informasi kepada remaja/mahasiswa dan keluarga remaja mengenai perencanaan kehidupan berkeluarga di Kota Yogyakarta yang dituangkan ke dalam Program Generasi Berencana (GenRe).

Seiring dengan berbagai permasalahan remaja, Dinas Pengendalian Penduduk dan Keluarga Berencana Kota Yogyakarta berupaya untuk memecahkan dan mengatasi permasalahan remaja di Kota Yogyakarta. Adapun upaya yang dilakukan Dinas Pengendalian Penduduk dan Keluarga Berencana Kota Yogyakarta yaitu: 1) Sosialisasi Pusat Infrormasi dan Konseling Remaja (PIK R) dan GenRe (Generasi Berencana) di jalur sekolah maupun wilayah, 2) Pelatihan Konseling bagi Konselor Sebaya dan Pendidik Sebaya $=50$ orang tiap angkatan / sekitar 300 remaja, 3) Promosi PIK $\mathrm{R}$ dan GenRe melalui Ajang
Kreatifitas Seni Remaja, 4) Jambore Remaja yang diadakan hampir tiap tahun, masing-masing angkatan :180 remaja, 5) Lomba PIK $\mathrm{R}$ jalur sekolah maupun wilayah, 6) Pemilihan Duta Remaja Kota Yogyakarta tiap dua tahun sekali, 7)Pemberian dana operasional kelompok PIK R dan BKR, bagi 54 kelompok PIK R dan bagi 88 kelompok BKR di Kota Yogyakarta, 8) Keterpaduan antara PIK R dan BKR.

\section{Efektivitas Pelaksanaan Program Generasi Berencana (GenRe) di Kota Yogyakarta.}

1. Tepat Kebijakan

Ketepatan kebijakan ini dinilai dari sejauh mana kebijakan yang ada telah bermuatan hal-hal yang memang memecahkan masalah yang hendak dipecahkan. Sisi kedua kebijakan adalah apakah kebijakan tersebut sudah dirumuskan sesuai dengan karakter masalah yang hendak dipecahkan, sisi ketiga adalah apakah kebijakan dibuat oleh lembaga yang mempunyai kewenangan (misi kelembagaan) yang sesuai dengan karakter kebijakannya.

$$
\text { Substansi Program Generasi }
$$
Berencana (GenRe) sudah memuat halhal untuk memecahkan dan mengatasi masalah. Namun, arah kebijakan yang 
diwujudkan dalam kegiatan-kegiatan belum tepat dalam memuat hal-hal untuk memecahkan dan mengatasi masalah. Arah kebijakan belum efektif dalam mengatasi permasalaahan remaja di Kota Yogyakarta karena arah kebijakan lebih kepada pencegahan, belum kepada arah kebijakan yang menangani masalah.

\section{Tepat Pelaksanaan}

Aktor yang terlibat dalam pelaksanaan Program Generasi Berencana di Kota Yogyakarta yaitu ; 1) Tingkat Kota yaitu Dinas Pengendalian Penduduk dan Keluarga Berencana Kota Yogyakarta; 2) Tingkat Kecamatan dan Tingkat Kelurahan yaitu PLKB/PKB Kecamatan; 3) Pengelola PIK R/M di Kota Yogyakarta; 4) Kader BKR di Kota Yogyakarta. 5) Pembina PIK R/M ; 6) Remaja 10-24 tahun yang belum menikah. 7) Keluarga yang memiliki remaja. Dalam pelaksanaan Program Generasi Berencana (GenRe) pengelola Program Generasi Berencana (GenRe) menjalin kerjasama dengan pemangku kepentingan dan mitra kerja.

Aktor yang terlibat pada pelaksanaan Program Generasi Berencana di Kota Yogyakarta kurang efektif. Ketepatan pelaksana terlihat dari adanya kerjasama yang terjadi antar aktor pelaksana Program Generasi Berencana di
Kota Yogyakarta. Namun, kerjasama dan penyesuaian tugas dan kewenangan masih terkendala pada keterbatasan sumberdaya manusia.

3. Tepat Target

Meskipun target yang diintervensi sudah sesuai dengan yang direncanakan namun target sasaran belum maksimal kesiapannya untuk diintervensi. Selain itu, program yang bersifat memperbaruhi program sebelumnya ini, belum mampu untuk menurunkan angka permasalahan remaja. Belum adanya ketepatan target karena belum maksimalnya kesiapan target yang diintervensi.

Kesiapan target sasaran program belum efektif karena masih ada target sasaran yang belum siap diintervensi. Masih ada remaja yang menganggap tabu untuk membicarakan substansi Program Generasi Berencana seperti Kesehatan Reproduksi Remaja.

4. Tepat Lingkungan

Ketepatan lingkungan dilihat dari lingkungan kebijakan dan lingkungan ekternal. Ketepatan lingkungan kebijakan cukup efektif karena interaksi di antara lembaga-lembaga perumus kebijakan dan pelaksana kebijakan dengan lembaga lain yang terkait sudah cukup baik.

Sedangkan, lingkungan eksternal belum efektif karena karena masih adanya 
opini publik yang belum paham benar apa substansi yang diperjuangkan Program Generasi Berencana (GenRe) dan belum mendukung Program Generasi Berencana (GenRe) di Kota Yogyakarta.

Interaksi antara lembaga- lembaga terkait yang terjadi dalam prelaksanaan Program Generasi Berencana di Kota Yogyakarta dalam hal tepat lingkungan ini adalah, adanya peran BKKBN DIY dan DPPKB Kota Yogyakarta yang turut memegang peran penting dalam pelaksanaan Program Generasi Berencana. Secara umum, interaksi lingkungan internal dilakukan untuk mendukung tupoksi masing-masing dan memantau agar pelaksanaan Program Generasi Berencana dapat berjalan lancar di lapangan.

$$
\text { Meskipun pada ketepatan }
$$
lingkungan kebijakan sudah cukup efektif, namun ketepatan lingkungan eksternal masih kurang efektif. Kurang efektif lingkungan eksternal karena masih adanya opini publik yang belum paham benar apa substansi yang diperjuangkan Program Generasi Berencana (GenRe) dan belum mendukung Program Generasi Berencana (GenRe) di Kota Yogyakarta.

\section{Tepat Proses}

Ketepatan proses pelaksanaan Program Generasi Berencana (GenRe) di
Kota Yogyakarta belum efektif. Kurang efektif ketepatan proses dapat terlihat dari publik yang belum memahami benar apa substansi Program Generasi Berencana (GenRe) yang diperjuangkan dan manfaatnya apa bagi mereka khususnya dan masyarakat umumnya. Publik yang belum memahami benar Program Generasi Berencana (GenRe) cenderung belum menerima arah kebijakan.

Hal ini sebagaimana diungkapkan oleh Ibu Heristanti Kabid Keluarga Berencana dan Pembangunan Keluarga DPPKB Kota Yogyakarta yang menyatakan bahwa belum semua remaja tertarik dengan GenRe ini dan PIK R. Hal tersebut yang menunjukkan publik belum memahami dan belum siap untuk melaksanakan/menjadi bagian dari Program Generasi Berencana di Kota Yogyakarta. Dengan demikian, pelaksanaan program Generasi Berencana di Kota Yogyakarta belum efektif.

Selain itu, kurangnya kesediaan dan minat target sasaran untuk berpartisipasi dalam PIK R dan BKR juga menunjukkan bahwa belum adanya penerimaan dari masyarakat di Kota Yogyakarta. Kesiapan publik melaksanakan/menjadi bagian dari Program Generasi Berencana di Kota Yogyakarta belum cukup siap. 
Partisipasi masyarakat terhadap adanya PIK R/M dan BKR masih rendah

Faktor Pendukung dan Faktor Penghambat Efektivitas Pelaksanaan Program Generasi Berencana (GenRe) di Kota Yogyakarta.

\section{Faktor Pendukung}

Faktor pendukung yang ada dalam penelitian ini adalah adanya media komunikasi. Media komunikasi sangat mendukung pelaksanaan Program Generasi Berencana. Media komunikasi seperti media sosial dan radio sangat mendukung dalam proses sosialisasi kegiatan terkait Program Generasi Berencana (GenRe). Selain itu, media komunikasi melalui aplikasi whatsapp dan bbm juga sangat mendukung dalam komunikasi antar aktor pelaksana Program Generasi Berencana (GenRe) di Kota Yogyakarta.

Adanya media komunikasi seperti media sosial sangat mendukung pelaksanaan Program Generasi Berencana (GenRe). Pada masa ini, hampir semua remaja aktif menggunakan internet untuk mengakses media sosial seperti instagram, twitter, dan facebook.

Faktor pendukung selanjutnya yaitu adalanya pelatihan konseling. Pelatihan Konseling ini dapat memberikan keterampilan dan memahami dasar sebagai pendidik sebaya dan konselor sebaya. Sehingga terwujud tegar remaja yaitu remaja yang berperilaku sehat terhindar dari resiko TRIAD KRR. Pelatihan konseling ini menjadi faktor pendukung dalam pelaksanaan Program Generasi Berencana.

Adanya pelatihan konseling ini sangat mendukung pelaksanaan Program Generasi Berencana (GenRe). Melalui pelatihan ini peserta bisa menjadi pendidik sebaya dan konselor sebaya yang handal, berkualitas, dan mampu memberikan informasi, konseling dan pelayanan tentang permasalahan remaja sekitarnya. Pelatihan yang dilaksanakan kepada pengelola PIK R/M dan BKR dapat meningkatkan kompetensi pengelola PIK R/M dan BKR.

2. Faktor Penghambat

Rendahnya partisipasi masyarakat menjadi faktor penghambat dalam pelaksanaan program Generasi Berencana di Kota Yogyakarta. Partisipasi masyarakat memiliki peranan penting dalam suatu program. Partisipasi remaja dan keluarga yang memiliki dalam program Generasi Berencana di Kota Yogyakarta terbilang belum baik, dimana masyarakat yang menjadi sasaran program belum berperan aktif dari awal 
hingga akhir. Sehingga dengan rendahnya partisipasi masyarakat pada Program Generasi Berencana belum terlaksana dengan efektif.

Faktor penghambat selanjutnya yaitu adanya penyimpangan moral. Penyebab terjadinya krisis moral yang menimpa remaja diantaranya adalah kurangnya perhatian dari keluarga, pergaulan yang tidak baik, dan lingkungan tempat tinggal yang kurang baik. Semua ini tidak terlepas dari peran orang tua yang seharusnya dapat mengontrol tingkah perilaku mereka dalam kehidupan sehari-hari dalam melakukan kegiatan sehari-hari.

Pergeseran perilaku remaja karena adanya norma-norma yang semakin kabur sehingga remaja melakukan penyimpangan. Namun karena sifatnya yang abstrak membuat kebudayaan dan norma-norma tersebut semakin tergerus. Ketika gaya pakaian ala kebarat-baratan yang tidak sesuai dengan norma kesopanan dan adat istiadat suatu daerah yang dulunya hanya bisa dilihat di televisi dan majalah tetapi sekarang remaja bisa melihat fashion, style, trend melalu majalah dan televisi, bukan hanya melihat, mereka bisa mencoba dan merasakan trend tersebut tinggal pilih dan beli. Sekarang mencoba sesuatu yang baru tetapi tidak sesuai dengan norma-norma dan adat istiadat adalah menjadi hal yang biasa untuk para remaja.

Faktor penghambat selanjutnya yaitu keterbatasan waktu yang dimiliki pengurus PIK R. Pengelola PIK R/M merupakan remaja/mahasiswa berusia maksimal 24 tahun sehingga ada remaja yang mempunyai kesibukan sekolah dan ada mahasiswa yang mempunyai kesibukan kuliah. Hal itulah yang menjadi penghambat, jadwal dan kesibukan yang dimiliki satu orang dengan orang yang lainnya berbeda-beda.

\section{SIMPULAN}

Berdasarkan hasil penelitian dan pembahasan tentang pelaksanaan Program Generasi Berencana di Kota Yogyakarta maka dapat ditarik kesimpulan bahwa pelaksanaan Program Generasi Berencana di Kota Yogyakarta belum efektif dilihat dari indikator yang ada yakni tepat kebijakan, tepat pelaksana, tepat target, tepat lingkungan, dan tepat proses. Terdapat beberapa faktor pendukung dan faktor penghambat dalam pelaksanaan program Generasi Berencana di Kota Yogyakarta. Faktor pendukung yaitu kemudahan dari komunikasi dan adanya pelatihan konseling. Sedangkan faktor penghambat yaitu rendahnya 
partisipasi masyarakat, adanya penyimpangan moral pada remaja, dan keterbatasan waktu yang berbeda- beda setiap individu.

\section{DAFTAR PUSTAKA}

Agung Kurniawan. 2005. Transformasi Pelayanan Publik. Yogyakarta: Pembaruan.

BKKBN. 2012. Grand Design Program Pembinaan Ketahanan Remaja. Jakarta : BKKBN.

BKKBN. 2012. Pedoman Pengelolaan PIK R/M. Jakarta : BKKBN.

BKKBN. 2012. Pedoman Pengelolaan Bina Keluarga Remaja. Jakarta: BKKBN.

Georgopolous. 1985. Efektivitas Organisasi. Jakarta : Erlangga.

Kristian Widya Wicaksono. 2006. Administrasi dan Birokrasi Pemerintahan. Yogyakarta: Graha Ilmu

Lubis, Hari. 1987. Teori Organisasi (Suatu Pendekatan Makro). Jakarta: UI.

Mahmudi. 2005. Manajemen Kinerja Sektor Publik. Yogyakarta:UPP AMP YKPN.

Mardalis. 2002. Metode Penelitian. Jakarta: Bumi Aksara.

Moleong, Lexy. 2005. Metode Penelitian Kualitatif. Bandung :PT Remaja Rosdakarya.

Nugroho, Riant . 2011. Public Policy: Dinamika Kebijakan - Analisis Kebijakan-Manejemen Kebijakan. Jakarta: Elex Media Komputindo.
Handayaningrat, Soewarno. (1994). Pengantar Studi Ilmu Administrasi dan Manajemen. Jakarta: CV Hajimasagung.

Santrock, John W. (2007). Perkembangan Remaja. Alih Bahasa: Shinto B. Adelar dan Sherly Saragih. Jakarta: Penerbit Erlangga.

Siagian, Sondang. (1987). Manajemen Modern. Jakarta PT Gunung Agung.

Steers, Richard. (1985). Efektivitas Organisasi.Jakarta: Erlangga.

Subarsono. (2013). Analisis Kebijakan Publik. Yogyakarata: Pustaka Pelajar

Sugiyono. (2011). Metode Penelitian Kuantitatif, Kualitatif, dan $R \& D$. Bandung: Alfabet.

Sugiyono. (2013). Metode Penelitian Pendidikan: Pendekatan Kuantitatif, Kualitatif, dan $R \& D$. Bandung: Alfabet.

Sukandar Rumidi. (2002). Metodologi Penelitian Petunjuk Praktis Untuk Peneliti Pemula. Yogyakarta: Gajah Mada University Pres.

Tangkilisan, Hesel Nogi. (2003). Implementasi Kebijakan Publik. Yogyakarta Lukman Offset YPAPI 